\title{
IDH Gene Family Mutation Status Unknown
}

National Cancer Institute

\section{Source}

National Cancer Institute. IDH Gene Family Mutation Status Unknown. NCI Thesaurus.

Code C129288.

A finding indicating that there is no information regarding the presence or absence of IDH1 or IDH2 gene mutations in a tumor sample. 